\begin{tabular}{l|l|l} 
Jurnal Eksplorasi Akuntansi (JEA) & $\begin{array}{l}\text { e-ISSN : 2656-3649 (Online) } \\
\text { hol. 3, No 4, November 2021, Hal 822-835 }\end{array}$
\end{tabular}

\title{
Pengaruh Kompetensi, Sistem Pengendalian Internal, Peran Perangkat Desa, dan Kualitas Penyajian Laporan Keuangan terhadap Akuntabilitas Pemerintah Desa dalam Mengelola Alokasi Dana Desa
}

\author{
Wahyu Ramadhan ${ }^{1^{*}}$, Fefri Indra Arza ${ }^{2}$ \\ 1,2 Fakultas Ekonomi, Universitas Negeri Padang \\ *Korespondensi: wahyuramadhan007s@gmail.com
}

\begin{abstract}
This study aims to determine the Effect of Competence, Internal Control System, Role of Village Apparatus and Quality of Financial Statement Presentation on Village Government Accountability in Managing Village Fund Allocation (ADD) (Empirical Study in Nagari district of Solok). The data in this study used primary data obtained from the village apparatus. The sampling technique used random sampling method. The sample used in this study were 24 nagari in the district of Solok and the respondents were village officials who worked in the Wali Nagari office as many as 72 village officials. The village apparatus consists of the Village Head, Secretary, and Treasurer. Data analysis using multiple regression analysis. The results of this study indicate that (1) Competence has a positive and significant effect on Village Government Accountability in Managing Village Fund Allocations (ADD), (2) Internal Control System has a positive and significant impact on Village Government Accountability in Managing Village Fund Allocations (ADD), (3) The role of Village Apparatus has a positive and significant effect on Village Government Accountability in Managing Village Fund Allocations (ADD), (4) Quality of Financial Statement Presentation has a positive and significant impact on Village Government Accountability in Managing Village Fund Allocations (ADD).
\end{abstract}

Keywords: Competence; Internal Control System; Role of Village Apparatus.

How to cite (APA $6^{\text {th }}$ style)

Ramadhan, Wahyu \& Arza, F.I (2021). Pengaruh Kompetensi, Sistem Pengendalian Internal, Peran Perangkat Desa, dan Kualitas Penyajian Laporan Keuangan terhadap Akuntabilitas dalam Mengelola Alokasi Dana Desa. Jurnal Eksplorasi Akuntansi (JEA), 3 (4), 822-835.

\section{PENDAHULUAN}

Akuntabilitas adalah hal sangat berguna bagi setiap entitas pemerintahan ini merupakan bentuk sebagian dari pertanggungjawaban pemerintah kepada masyarakat, dengan ini akuntabilitas menjadian bagian penting dalam pemerintahan karena akuntabilitas memberikan sebuah bukti bahwa pemrintah bertanggung jawab apa yang di percayakan masyarakat kepada pemerintah untuk mengalokasikan dana-dana yang ada pada daerahdaerah itu sendiri, pada sektor publik akuntabilitas adalah hal yang wajib ada keberadaanya. Entitas publik menilai ini merupakan hal penting yang harus dimiliki oleh pemerintah 
dikarenakan akuntabilitas ini dapat mengakibatkan kepercayaan masyarakat kepada pemerintah semakin meningkat terhadap segala hal yang dikerjakan oleh pemerintah.

Scott (2006) menyatakan bahwa pemerintah merupakan orang yang mengursi sumber daya, masyarakat memerlukan segala informasi yang berterkait dengan kinerja apartur desa. Laporan ini cukup diperlukan oleh sekelompok orang gunanya untuk mencari tahu apakah desa memiliki cukup banyak sumber daya serta bagaimana pemerintah mendistribusikan kemampuan tersebut. pemikiran itu diperkuat (Jorgge et al. 2011) menegaskan bahwasanya masyrakat wajib tahu kemampuan yang dimiliki oleh daerah tersebut. Sehingga pemerintahan dapat memajukan desa tersebut dan rakyat harus memberikan dukungan penuh terhadap semua macam kegiatan yang dikerjakan oleh pemerintah.

Berdasarkan kabar yang beredar dan juga informasi dari www.harianhaluan.com terdapat dugaan kasus korupsi yang menyeret kepala desa dan beberapa aparatur di sebuah nagari Kabupaten Solok yang digunakan untuk kepentingan pribadi, Terungkapnya Kasus ini dugaan korupsi berawal dari kecurigaan petugas atas penggunaan anggaran dana desa yang dinilai cukup janggal. Dari pemeriksaan pihak terkait terhadap jumlah anggaran tersedia dengan anggaran yang terealisasi dan dihubungkan dengan buku kas umum tahun anggaran 2018, didapatkan Silpa sebesarRp.742.489.579. Namun saat dilakukan pengecekan terhadap kas yang ada di rekening nagari, hanya ada sebesar Rp143.349,59. Artinya, terdapat selisih anggaran sebesar Rp742.246.230 dan seharusnya berada dalam kas atau penguasaan bendahara nagari, Sementara dari hasil audit ahli sebagaimana yang dituangkan dalam Laporan Hasil Pemeriksaan (LHP) nomor 700/08/INSP-D/ATT/LHP/2019 dan ditambah dari perhitungan dari keterangan saksi, total kerugian negara mencapai lebih kurang Rp955.567.279.

Data diatas merupakan permasalahan yang terjadi pada salah satu nagari yang ada di Kabupaten Solok yang melibatkan kepala desa dan juga beberapa stafnya, yang artinya pengalokasian dana desa belum berjalan dengan semestinya dan kompetensi, pengendalian sistem internal, peran perangkat desa, dan kualitas penyajian laporan keuangan pada pemerintah daerah belum belum terbilang baik ini yang menjadi celah untuk melakukan kecurang - kecurangan pada daerah tersebut.

Akuntabilitas merupakan sebuah pengatur yang dimiliki oleh aparat desa yang berhubungan dengan apa yang dikerjakan oleh pemerintah desa, ini menjadi sebuah fungsi aparatur desa sebagai penyalur dan merupakan hal yang sangat menentukan atas tanggung jawab pemerintah desa kepada masyarakat, ini juga dapat membantu kesuksesan dalam menerapkan akuntabilitas pada sebuah entitas dan ini sangat berhubungan dengan teori institusional karena teori ini juga berhubungan dengan sebuah kelembagaan atau sebuah organisasi dimana teori ini akan mendasari sebuah organisasi atau enstitas pada pemerintahan yang gunanya adalah untuk memberikan penjelasan pemerintah dalam setiap keputusan yang telah diambil atau dibuatya.

Kompetensi atau kemampuan yang dimiliki oleh aparatur pemerintah juga berpengaruh terhadap akuntabilitas pemerintahan daerah karena kompetensi inilah yanag akan menjadi acuan dalam melakukan pengalokasikan dana desa yang dimana kompetensi yang dimiliki aparatur desa tersebut akan menjadi peran besar dalam setiap tindakan dilakukan dan juga berperan besar atas keputusan yanga akan diambil oleh pemerintah kompetensi aparatur harus sama-sama bersinergi agar dapat melakukan pencegahan terhadap terjadinya kecurangan (fraud).

Peran perangkat desa merupakan merupakan sebuah peran yang dimiliki apartur agar dapat membantu Kepala Desa dalam membuat kebijakan dan rancangan yang ada dalam pemerintahan desa dan berkontribusi penuh untuk membantu Kepala Desa dalam melaksanakan kebijakan yang telah dibuat. Pernyataan Permendagri No. 113 Tahun 2014 perihal mengelola dana Desa, Pemimpin desa melakukan pembentuakan PTPKD (Pelaksana 
Teknis pengelola Keuangan Desa) ini adalah sebagian dari unsur perangkat desa. Dengan ini perangkat desa memiliki andil pada rancangan dana desa ini telah sesuai dengan aturan yang telah disahkan maka terbentuklah akuntabilitas dan Sistem Pengendalian Internal juga berfungsi dalam terbentuknya pengelolaan dana desa yang memuaskan ini juga berhubungan teori institusional yang dimana teori ini menjelaskan tentang berprilaku pada sebuah kelembagaan atau organisasi.

Kualitas penyajian laporan keuangan menjadi proses terpenting dari organisasi untuk mengetahui bagaimana kinerja atau eksistensi suatu organisasi dalam satu periode. Kualitas penyajian laporan keuangan pemerintah daerah dinilai setiap tahunnya oleh Badan Pemeriksa Keuangan (BPK) selaku auditor pemerintah. BPK dapat memberikan empat jenis opini terhadap laporan pertanggungjawaban yang disajikan oleh pemerintah, yaitu Wajar Tanpa Pengecualian (WTP) termasuk Wajar Tanpa Pengecualian dengan Paragraf Penjelas (WTPDPP), Wajar Dengan Pengecualian (WDP), Tidak Wajar (TW) dan Tidak Memberi Pendapat (TMP). Ketika BPK memberi Opini Wajar Tanpa Pengecualian (WTP) terhadap LKPD, hal ini berarti laporan keuangan suatu pemerintah daerah disajikan dan diungkapkan secara wajar dan berkualitas. Representasi kewajaran dituangkan dalam bentuk opini dengan cara mempertimbangkan terhadap kriteria kesesuaian laporan keuangan dengan Standar Akuntansi

Pemerintahan (SAP), kecukupan pengungkapan, kepatuhan terhadap peraturan perundangundangan, dan efektivitas pengendalian internal (BPK, 2014 dalam Indriasih, 2014). Setelah itu, laporan keuangan pemerintah disampaikan kepada DPR/DPRD.

Desa adalah sebuah daerah kecil baik sebagai tempat tinggal dan juga tempat berlansungnya kehidupan yang bergantung pada hasil alam (Raharjo,2010). Masyarakat sendiri adalah sekumpulan orang yang saling menjalin ikatan sehingga membentuk kesepakatan-kesepakatan yang bisa diterapkan oleh seluruh warga desa. Kesepakatan ini akan menjadi pedoman hidup warga desa tersebut, sehingga dapat membedakan antara warga satu sama lain (Soerjono Soekanto, 2006 : 22). Berdasarkan PP No. 72 Tahun 2005 tentang Desa pasal 68 ayat 1 poin c, menyatakan bahwasanya desa akan menerima paling rendah $10 \%$ dari pemerintah pusat, dana diberikan dalam bentuk Alokasi dana Desa. Dana Ini adalah dana yang diberikan Pemerintahan Kabupaten kepada desa, sumber dana ini dari pemerintah pusat yang akan di terima oleh pemerintah desa, Dana ini berguna untuk menjalankan programprogram desa.

Alokasi Dana Desa harus digunakan dan di alokasikan sebagaimana mestinya sesuai dengan undang - undang dan ketentuan yang berlaku yang telah ditetapkan pemerintah Indonesia. Perencanaan program mengelola Alokasi Dana Desa pada desa - desa dikecamatan kabupaten solok secara perlahan telah melakukan rancangan pengembangan dan keikutsertaan masyarakat desa, dalam menggunakan prinsip partisipatif, respondif dan transparan serta pertanggungjawaban secara teknis sudah cukup baik.

\section{REVIU LITERATUR DAN PENGEMBANGAN HIPOTESIS Teori institusional (Institutional Theory)}

Teori Institusional (Institusional Theory) atau teori kelembagaan yaitu terbentuknya organisasi karena adanya tekanan lingkungan institutional yang mengakibabkan terjadinya institutionalisasi. Pemikiran yang mendasari teori ini teori untuk bertahan hidup, sebuah organisasi harus mampu meyakinkan publik atau masyarakat bahwasanya organisasi adalah suatu entitas yang sah (legitimate) serta layak untuk didukung. Teori Institusional yang dikemukakan oleh Scott (2008) mengatakan bahwa teori ini digunakan untuk menjelaskan prilaku dalam pengambilan keputusan pada sebuah organisasi publik.

\section{Akuntabilitas}

Menurut (Supriyono, 2009) Akuntabilitas merupakan kewajiban dari individu yang dipercaya mengelola sumber daya publik untuk mempertanggungjawabakan bebagai hal, baik 
yang menyangkut fiskal manajerial maupun program. Akuntabilitas merupakan sebuah pengedali penuh aparat atas segala hal yang dikerjakan oleh pemerintah, sehingga tugas pemerintah sebagai penyalur adalah hal yang perlu ada dalam hal mempertanggungjawabkan segala macam kegiatan dari pemerintah kepada masyarakat.

\section{Kompetensi}

Menurut (Wibowo, 2014) Kompetensi adalah kemampuan atau karakteristik yang dimiliki seseorang untuk melaksanakan atau melakuan suatu pekerjaan atau tugas yang dilandasi pengetahuan, keterampilan, dan didukung oleh sikap prilaku yang dituntut oleh pekerjaan tersebut. Kompetensi dapat diartikan sebagai kecakapan, keterampilan, kemampuan. Kata dasarnya sendiri, yaitu kompeten, yang berarti cakap, atau terampil. Pada konteks manajemen Sumber Daya Manusia, istilah kompetensi mengacu kepada atribut / karakteristik seseorang yang membuatnya berhasil dalam pekerjaannya, kompetensi (competency) sebagai karakteristik yang mendasar yang dimiliki seseorang yang berpengaruh langsung terhadap kinerja yang sangat baik.

\section{Sistem Pengendalian Intern}

Menurut Matamande, et al. (2012), sistem pengendalian intern adalah menempatkan satu set kebijakan organisasi dan disetujui proses pengendalian intern dibuat oleh manajemen suatu organisasi untuk mencapai tujuan utama manajemen dan memastikan bisnis beroperasi sempurna. Sistem Pengendalian Intern (SPI) merupakan sistem yang diperlukan dalam kelancaran perencanaan dilakukan secara terus menerus mulai dari pemimpin sampai ke karyawan tanpa kecuali guna memberi keyakinan atas pencapaian entitas, PP No. 60 tahun 2008 tentang SPIP yang mengatur tentang Pengawasan Intern atas Penyelenggaraan Tugas dan Fungsi Instansi Pemerintahan. Inspektorat daerah adalah pengawas internal dan keberadaan inspektorat ini sangatlah penting karena tugas utamanya adalah melakukan pengawasan terhadap kinerja pemerintahan. (Aikins 2011).

\section{Peran Perangkat Desa}

Perangkat desa merupakan orang-orang yang mempunyai peranan penting dalam meningkatkan kemajuan bangsa melalui desa. Perangkat desa merupakan bagian dari unsur pemerintah desa yang terdiri dari sekretaris desa dan perangkat desa lainnya yang merupakan aparatur desa dibawah naungan kepala Desa (Gunawan, 2013). Perangkat desa diminta dapat mengelola segala sumber daya yang dimiliki secara baik yang bercirikan demokratis juga desentralistis. Peran dapat dijelaskan sebagai salah satu hubungan suatu perilaku yang ditimbulkan oleh suatu jabatan tertentu.

\section{Penyajian Laporan Keuangan}

Menurut (Halim dan Abdullah 2008) menyatakan bahwa penyajian laporan keuangan adalah salah satu bentuk pelaksanaan akuntabilitas pengelolaan keuangan publik. Penyajian laporan keuangan adalah hal yang terencana mengenai posisi keuangan dan transaksi yang dilakukan oleh suatu organisasi. Laporan keuangan pada entitas sektor publik merupakan komponen penting untuk mencapai akuntabilitas yang baik pada sektor publik.

\section{Pengaruh Kompetensi Terhadap Akuntabilitas Pemerintah Desa dalam mengelola Alokasi Dana Desa (ADD)}

Kompetensi dan pengetahuan harus dimiliki oleh setiap aparatur pemerintah daerah. Jika aparatur pemerintah derah memiliki kompetensi yang memadai maka ini akan menjadi suatu perubahan dan peningkatan pada daerah tersebut. Kompetensi aparatur ialah aspek penting yang harus dimiliki oleh seseorang untuk mencapai kinerja yang bagus. Hal-hal pribadi tersebut adalah sifat, sikap, wawasan dan keahlian. Kompetensi aparatur merupakan 
salah satu hal berguna dalam kompetensi. Berdasarkan penelitian di atas maka peneliti dapat merumuskan hipotesis penelitian sebagai berikut:

H1: kompetensi berpengaruh positif terhadap akuntabilitas pemerintah desa dalam mengelola Alokasi Dana Desa (ADD).

\section{Pengaruh Sistem Pengendalian Internal terhadap Akuntabilitas Pemerintah Desa dalam mengelola Alokasi Dana Desa (ADD)}

Sistem Pengendalian Internal merupakan hal yang berguna, ini disebabkan dengan adanya sytem controlling dapat berpengaruh pada pengambilan keputusan pada pemerintahan desa dan juga memberikan implikasi terhadap akuntabilitas pemerintah desa. Sistem pengendalian Internal pada Aparatur Pemerintah Desa memberikan pengaruh positif terhadap akuntabilitas dalam pengelolaan ADD. Hal ini selaras dengan yang di kemukakan oleh (Aikin 2011) bahwasanya kontrol pemerintah dalam meningkatkan akuntabilitas dengan melalui penilaian dan perbaikan pengendalian internal. Maka peneliti dapat merumuskan hipotesis penelitian sebagai berikut:

H2: Sistim Pengendalian Internal berpengaruh positif terhadap Akuntabilitas Pemerintah Desa dalam Mengelola Alokasi Dana Desa (ADD).

\section{Pengaruh Peran Perangkat Desa terhadap Akuntabilitas Pemerintah Desa dalam mengelola Alokasi Dana Desa (ADD)}

Perangkat desa berperan penting dalam kemajuan bangsa melalui desa. Perangkat desa yang terdiri dari kepala, sekretaris, dan perangkat desa lainnya yang merupakan aparatur desa dibawah pengawasan kepala Desa. Perangkat desa diberi kepercayaan dalam mengelola sumber daya yang dimiliki secara baik. Pada penelitian yang dilakukan Neny Tri Indrianasari (2017) dapat dilihat bahwa perangkat desa memiliki peran dalam mengelola dana desa dan secara keseluruhan pelaksanaan pengelolaan keuangan desa sesuai dengan Permendagri No. 113 Tahun 2014. Maka peneliti dapat merumuskan hipotesis penelitian sebagai berikut:

H3: Peran Perangkat Desa berpengaruh positif terhadap Akuntabilitas Pemerintah Desa dalam mengelola Alokasi Dana Desa (ADD).

\section{Pengaruh Penyajian Laporan Keuangan terhadap Akuntabilitas Pemerintah Desa dalam mengelola Alokasi Dana Desa (ADD)}

Kualitas penyajian Laporan Keuangan berpengaruh positif, berarti semakin bagus penyajian laporan keuangan maka akuntabilitas akan meningkat. Berdasarkan hasil penilitian ini menyatakan bahwasanya aparat pemerintah desa telah menyiapkan laporan keuangan yang memberisikan informasi ini dapat berpengaruh pada pengambilan, Kesalahan dalam laporan keuangan dapat diminimalisir dan disajikan dengan tepat waktu. Dalam penyusunan laporan keuangan selalu memakai kata yang dapat dimengerti oleh pembaca. Dengan itu, laporan keuangan yang berhubungan dengan penggunaan ADD diharapkan dapat pengguna merasa puas. Apabila kualitas laporan keuangan desa cukup bagus, dengan itu seluruh aktivitas yang berhubungan dengan pengelolaan dana desa dapat dipertanggungjawabkan. Maka peneliti dapat merumuskan hipotesis penelitian sebagai berikut.

H4: Penyajian laporan Keuangan berpengaruh positif terhadap Akuntabilitas Pemerintah

Desa dalam mengelola Alokasi Dana Desa (ADD).

\section{METODE PENELITIAN}

Penelitian ini menggunakan teknik statistik dan pendekatan kuantitatif. Jenis penelitian ini adalah kausatif, yang merupakan hubungan yang bersifat sebab akibat dengan dua variabel atau lebih. Populasi dalam penelitian ini yaitu pada nagari - nagari 
dikabupaten solok yang berjumlah 74 nagari. Sample pada penelitian ini memakai metode yaitu Random sampling merupakan pengambilan sample dari populasi yang ada secara acak tanpa menentukan strata atau level populasi tersebut. metode ini merupakan bagian dari teknik Probability Sampling yaitu teknik pengambilan sampel yang memberikan peluang yang sama bagi setiap unsur (Sugiyono, 2017).

Teknik pengumpulan data yang dilakukan pada penelitian ini menggunakan kuesioner dengan cara membagi angket kuesioner yang berisi pernyataan yang sudah disiapkan alternatif jawabannya. Kuesioner merupakan teknik pengumpulan data yang dilakukan dengan cara memberi beberapa pertanyaan atau pernyataan tertulis kepada responden untuk dijawab (Sugiyono, 2011). Kuesioner diantarkan langsung ke alamat responden. Dalam tahap pembagian kuesioner, peneliti membagikan.

Jenis data yang dipakai pada penelitian ini adalah data subjek. Sumber data dari penelitian ini adalah Data Primer, Data primer diperoleh dengan menggunakan kuesioner. Penelitian ini diproleh dari jawaban atas kuesioner yang dibagikan kepada responden. Teknik pengumpulan data yang dilakukan pada penelitian ini menggunakan kuesioner dengan cara membagi angket kuesioner yang berisi pernyataan yang sudah disiapkan alternatif jawabannya. Kuesioner diantarkan langsung ke alamat responden. Dalam tahap pembagian kuesioner, peneliti membagikan.

\section{Variabel Penelitian dan Pengukuran}

Variabel dependen dalam penelitian ini adalah Akuntabilitas pemerintah Desa dalam Menegelola Alokasi Dana Desa. Variabel Independen dalam penelitian ini adalah Kompetensi, Sistem Pengendalian Internal, Peran Perangkat Desa, dan Kualita Penyajian Laporan Keuangan. Dimana masing - masing variabel mengunakan pengukuran sebagai berikut :

Tabel 1

Pengukuran Variabel

\begin{tabular}{|c|c|c|}
\hline \multirow{3}{*}{$\begin{array}{l}\text { Variabel } \\
\text { Akuntabilitas }\end{array}$} & Indikator Pengukuran & Sumber \\
\hline & 1. Evaluasi atas kinerja keuangan. & \\
\hline & $\begin{array}{l}\text { 2. Tanggungjawab atas laporan } \\
\text { keuangan. }\end{array}$ & \\
\hline \multirow[t]{3}{*}{ Kompetensi. } & 1. Pengetahuan. & \\
\hline & 2. Kemampuan. & \\
\hline & 3. Keahlian. & \\
\hline Sistem Pengendalian & 1. Pengendalian resiko. & \\
\hline Internal. & $\begin{array}{l}\text { 2. Kegiatan penegendalian } \\
\text { informasi dan komunikasi. }\end{array}$ & \\
\hline \multirow[t]{2}{*}{ Peran Perangkat Desa. } & $\begin{array}{l}\text { 1. Keterlibatan dalam menyusun } \\
\text { laporan keuangan. } \\
\text { 2. Keterlibatan dalam nerencanaan }\end{array}$ & Artikel "Ely Ayuning Astuty \\
\hline & $\begin{array}{l}\text { 2. Keterirbatan dalam perencanaan } \\
\text { penggunaan laporan keuangan. }\end{array}$ & \\
\hline Kualitas Penyajian & 1. Relevan. & \\
\hline Laporan Keuangan. & 2. Andal. & \\
\hline
\end{tabular}

\section{Metode Analisis Data}

Analisis data dalam penelitian ini menggunakan analisis regresi linear berganda menggunakan program SPSS v.28. Tahapan yang digunakan dalam menguji hipotesis pada penelitian ini adalah analisis statistik deskriptif, uji asumsi klasik, analisis regresi berganda dan uji hipotesis. 


\section{HASIL DAN PEMBAHASAN}

Subjek pada penelitian ini yaitu 74 nagari yang ada di kabupaten solok, dari sebanyak populasi tersebut diambil sebanyak 24 nagari dan teknik yang digunakan yaitu random sampling. Sampel yang digunakan dalam penelitian ini adalah 24 nagari dikabupaten solok dan yang menjadi respondennya yaitu aparatur desa yang bekerja di kantor Wali Nagari sebanyak 72 aparatur desa. Aparatur desa ini terdiri dari Kepala Desa, Sekretaris, dan Bendahara.

\section{Uji Asumsi Klasik}

\section{Uji Normalitas}

Alat uji normalitas yang digunakan untuk menguji data yang berdistribusi normal adalah One Sample Komogorov-Smirnov (KS). Jika nilai signifikansi $>0,05$ maka Ho diterima (berdistribusi normal) (Ghozali,

Tabel 2

Hasil Uji Normalitas One-Sample Kolmogorov - smirnov Test

\begin{tabular}{lll}
\hline & & Unstandardized Residual \\
\hline $\mathrm{N}$ & & 65 \\
Normal Parameters (a,b) & Mean &, 0000000 \\
& Std.Deviation & 2,55467246 \\
Most Extreme & Absolute &, 169 \\
Differences & & 123 \\
& Positive &,- 169 \\
& Negative & .364 \\
\multicolumn{2}{c}{ Kolmogorov-Smirnov Z } &, 128 \\
Asymp, Sig. (2-tailed) & \\
\hline
\end{tabular}

a. Test distribution is normal.

b. Calculated from data.

Berdasarkan tabel di atas, maka diperoleh nilai signifikansi (Asym.Sig2- tailed) sebesar 0,128 besar dari 0,05. Artinya residual terdistribusi secara normal.

\section{Uji Multikolonieritas}

Uji multikolonieritas digunakan untuk mengetahui ada atau tidaknya penyimpangan asumsi klasik multikolonieritas kedua variabel. Uji multiklolinearitas dengan melihat nilai inflation factor (VIF) pada model regresi, jika VIF kurang dari 10, maka variabel tersebut tidak mempunyai persoalan multiklolinearitas dengan variabel bebas lainnya.

\section{Tabel 3}

Hasil uji Multiklolinearitas

\begin{tabular}{llcc}
\hline \multicolumn{1}{c}{ Model } & \multicolumn{2}{c}{ Collinearity Statistics } \\
& & Tolerance & VIF \\
\hline 1. Kompetensi &, 371 & 2,694 \\
2. Sistem Pengendalian internal &, 328 & 3,048 \\
3. Peran perangkat desa &, 523 & 1,911 \\
4. Kualitas penyajian laporan keuangan &, 461 & 2,433 \\
\hline
\end{tabular}

Berdasarkan tabel diatas, maka dapat diketahui nilai VIF ketiga variabel tersebut kurang dari 10, sehingga dapat disimpulkan bahwa model regresi tidak terjadi persoalan multiklolinearitas. 


\section{Uji Heteroskedaritas}

Uji heteroskedasitas digunakan untuk mengetahui ada atau tidaknya penyimpangan asumsi klasik. Jika signifikansi hasil korelasi lebih kecil dari 0,05 (5\%) maka persamaan regresi mengandung heteroskedasitas dan sebaliknya non heteroskedasitas atau homokedasitas.

Tabel 4

Hasil uji heterokedastisitas

\begin{tabular}{llll}
\hline No & \multicolumn{1}{c}{ Variabel Independen } & Sig (2-tailed) & \multicolumn{1}{c}{ Keterangan } \\
\hline 1. & Kompetensi &, 365 & Non Hetero \\
2. & Sistem Pengendalian internal &, 596 & Non Hetero \\
3. & Peran perangkat desa &, 151 & Non Hetero \\
4. & Kualitas penyajian laporan keuangan &, 254 & Non Hetero \\
\hline
\end{tabular}

Berdasarkan tabel diatas, maka dapat diketahui semua variabel yang diuji lebih besar dari $0,05(5 \%)$ atau tidak mengandung heteroskedasitas. Artinya tidak ada korelasi antara besarnya data residual sehingga data diperbesar tidak menyebabkan residual (kesalahan) semakin besar pula.

\section{Analisis Linear Berganda}

Tabel 5

Hasi Analisis Linear Berganda

\begin{tabular}{|c|c|c|c|c|c|c|}
\hline \multirow{2}{*}{\multicolumn{2}{|c|}{ Model }} & \multicolumn{2}{|c|}{$\begin{array}{l}\text { Unstandardized } \\
\text { Coefficients } \\
\text { Std }\end{array}$} & \multirow{2}{*}{$\begin{array}{c}\text { Standardized } \\
\text { Coefficients } \\
\text { Beta }\end{array}$} & \multirow[t]{2}{*}{$\mathbf{T}$} & \multirow[t]{2}{*}{$\begin{array}{l}\text { Sig. } \\
\text { Std . } \\
\text { Error }\end{array}$} \\
\hline & & $\boldsymbol{B}$ & Error & & & \\
\hline & (Constant) & 16,425 & 4,080 & & 4.026 & ,003 \\
\hline & Kompetensi &, 167 & 179 & ,112 & 849 & 009 \\
\hline & Sistem Pengendalian Internal & 216 &, 117 & 130 & ,231 & ,038 \\
\hline & Peran Perangkat Desa & ,150 & ,108 & 160 & ,458 & 029 \\
\hline & $\begin{array}{l}\text { Kualitas Penyajian Laporan } \\
\text { Keuangan }\end{array}$ & ,334 & ,296 & 183 & 1,393 & ,037 \\
\hline
\end{tabular}

Hasil dari analisis linear berganda tersebut dapat dimasukkan kedalam persamaan regresi sebagai berikut:

$Y=16,425+0,167 X 1+0,216 X 2+0,150 X 3+0,368 X 4+4,080$

\section{Uji R $\mathbf{R}^{2}$}

Tabel 6

Hasil Analisis Derteminan

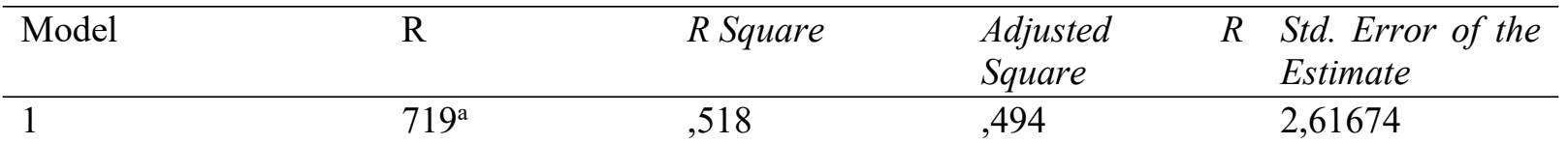

Berdasarkan tabel diatas diperoleh $\mathrm{R}$ sebesar 0,719 yaitu terdapat hubungan yang kuat positif antara variabel kompetensi (kompetensi, sistem pengendalian internal, peran perangkat desa dan Kualitas penyajian laporan keuangan) dengan variabel dependen (Akuntabilitas Pemerintah Desa) dan nilai koefisien determinansi atau ${ }^{2}$ (RSquare) sebesar 
0,494 atau (49,4\%). Hal ini menunjukkan bahwa persentase hubungan pengaruh variabel independen seraca bersama-sama (simultan) terhadap variabel dependen sebesar 49,4\%, sisanya $50,6 \%$ dipengaruhi atau dijelaskan oleh variabel lain yang tidak termasuk model penelitian ini.

\section{Uji F}

Tabel 7

Uji F (ANOVA(b))

\begin{tabular}{llllllr}
\hline Model & $\begin{array}{c}\text { Sum of } \\
\text { square }\end{array}$ & Df & Mean Square & $F$ & Sig. \\
\hline 1. Regression & 3.114 & 4 & 778 & 975 & $0,002^{\mathrm{b}}$ \\
Residual & 47.901 & 60 & 798 & & \\
Total & 51.015 & 64 & & & \\
\hline
\end{tabular}

a. Predictors : (Constant), Kompetensi, Sistem Pengendalian internal, Peran Perangkat Desa, dan Kualitas Penyajian Laporan Keuangan.

b. Dependent Variable: Akuntabilitas Pemerintah Desa

Berdasarkan tabel diatas diperoleh nilai Fhitung sebesar 0,975 dengan signifikan 0,002 nilainya lebih kecil dari tingkat signifikan $\propto 5 \%(0,05)$. Artinya bahwa Kompetensi, Sistem Pengendalian internal, Peran Perangkat Desa, dan Kualitas Penyajian Laporan Keuangan.secara bersama-sama berpengaruh positif dan signifikan terhadap Akuntabilitas Pemerintah Desa sekabupaten Solok.

\section{Peangaruh Kompetensi terhadap Akuntabilitas Pemerintah Desa}

Penelitian ini bertujuan seberapa pengaruh kompetensi terhadap akuntabilitas Pemerintah Desa. Dari hasil pengujian hipotesis ditemukan bahwa tingkat signifikansi untuk variabel kompetensi adalah 0,009 lebih kecil dibandingkan dengan $\alpha$ sebesar 0,05 (5\%). Hal ini berarti, kompetensi memiliki pengaruh positif dan signifikan terhadap akuntabilitas Pemerintah Desa dikabupaten Solok. Hasil penelitian ini juga sejalan dengan penelitian yang dilakukan oleh (Lamo,2015), penelitian ini menjelaskan bahwa kompetensi yang dimiliki kepala desa sekretaris dan bendahara desa berdampak positif terhadap akuntabilitas pemerintah dalam mengelola alokasi dana desa. Sesuai dengan teori stewardship dimana sifat manusia dapat dipercaya, mampu bertindak dengan penuh tanggung jawab. Sebagai steward pemerintah desa termotivasi untuk bertindak dengan penuh tanggung jawab, mempunyai integritas dan memiliki kejujuran terhadap pihak lain dalam hal ini masyarakat sebagai principal yang mesti diberikan pelayanan dan disejahterakan.

Hasil penelitian ini berbeda dengan hasil penelitian yang dilakukan oleh Diarespati (2017) yang menunjukan bahwa kompetensi aparatur dari Pemerintah Desa secara signifikan tidak mempengaruhi akuntabilitas pengelolaan keuangan Alokasi Dana Desa (ADD). Hal ini berbeda dengan hipotesis yang telah diajukan sebelumnya yang menyebutkan bahwa kompetensi mempengaruhi akuntabilitas pengelolaan Alokasi Dana Desa (ADD). Hal ini disebabkan Aparatur Pemerintah Desa yang melaksanakan pengelolaan administrasi keuangan belum sesuai dengan ketentuan - ketentuan berikut: (1) Kurang efektifnya sistem pembinaan dari pemerintah kecamatan dan pemerintah kabupaten terhadap pengelola Alokasi Dana Desa (ADD) ditingkat desa; (2) Rendahnya kompetensi maupun tingkat pendidikan yang merupakan ujung tombak pelaksanaan Alokasi Dana Desa (ADD). Hal ini didukung dengan hasil kuesioner dimana sebagian responden Aparatur Pemerintah Desa latar belakang pendidikannya di dominasi lulusan (SMA) sehingga rendahnya kompetensi Aparatur Pemerintah Desa akan mempengaruhi akuntabilitas dan transparansi pemerintah Desa.

Kompetensi aparatur merupakan aspek pribadi dari seorang pekerja yang memungkinkan seseorang mencapai kinerja yang baik. Aspek -aspek pribadi ini mencakup sifat, motif, 
sistem nilai, sikap, pengetahuan dan keterampilan dimana kompetensi akan mengarahkan tingkah laku, sedangkan tingkah laku akan menghasikan kinerja yang baik dan Kompetensi aparatur menjadi suatu faktor yang sangat penting mengingat kompetensi merupakan salah satu faktor internal dan menjadi suatu faktor yang sangat penting dalam pemerintahan.

Hasil penelitian ini menujukan bahwa kompetensi berpengaruh positif terhadap akuntabilitas pemerintah desa dalam mengelola alokasi dana desa, itu artinya responden setuju bahwa kompetensi sangat berpengaruh kepada akuntabilitas pemerintah desa dalam mengelola alokasi dana desa.

\section{Pengaruh Sistem Pengendalian Internal terhadap Akuntabilitas Pemerintah Desa}

Penelitian ini bertujuan seberapa pengaruh Sistem Pengendalian Internal terhadap akuntabilitas. Dari hasil pengujian hipotesis ditemukan bahwa tingkat signifikansi untuk variabel Sistem Pengendalian Internal adalah 0,009 lebih kecil dibandingkan dengan $\alpha$ sebesar 0,05 (5\%). Hal ini berarti, Sistem Pengendalian Internal memiliki pengaruh positif dan signifikan terhadap akuntabilitas Pemerintah Desa dikabupaten Solok. Penelitian ini juga sejalan dengan penelitian yang dilakukan Wardana (2016) dan Astuti (2016) yang menyatakan bahwa semakin baik pengendalian internal yang diimplementasikan dalam penyelenggaraan organisasi maka akan semakin akuntabel pengelolaan keuangan yang dilakukan.

Kegiatan yang dilakuakan dalam suatu pemerintahan mulai dari perencanaan, pelaksanaan pengawasan,sampai dengan pertanggungjawaban harus dilaksanakan secara tertib, terkendali serta efesien dan efektif. Untuk itu dibutuhkan suatu sistem yang dapat memberi keyakinan memadai bahwa penyelenggaraan kegiatan pada suatu instansi pemerintah dapat mencapai tujuannya secara efisien dan efektif, melaporkan pengelolaan keuangan secara andal, mengamankan aset dan mendorong ketaatan terhadap peraturan perundang - undangan. Sistem ini dikenal sebagai Sistem Pengendalian Internal.

Hasil penelitian ini diwajibkannya bisa memberikan implementasi sistem pengendalian internal pemerintah pada semua instansi pemerintah baik di tingkat pusat maupun daerah. Tujuan implementasi SPIP itu sendiri untuk memberi keyakinan tercapainya tujuan penyelenggaraan negara dengan efektif dan efisien, pelaporan keuangan yang andal, pengamanan aset negara dan ketaatan terhadap peraturan perundang-undangan. Apabila SPIP diterapkan dengan baik dan benar maka pengelolaan keuangan negara, daerah dan desa akan dilaksanakan dengan jujur dan taat pada regulasi sehingga akuntabilitas pengelolaan keuangan publik akan meningkat.

Hasil penelitian ini menujukan pengaruh positif terhadap akuntabilitas pemerintah desa dalam mengelola alokasi dana desa, itu artinya responden setuju bahwa sistem pengendalian internal sangat berpengaruh kepada akuntabilitas pemerintah desa dalam mengelola alokasi dana desa. Dari hasil pengujian tersebut, dapat disimpulkan bahwa semakin tinggi Sistem Pengendalian Internal maka akan meningkatkan akuntabilitas Pemerintah Desa tersebut.

\section{Pengaruh Peran Perangkat Desa terhadap Akuntabilitas Pemerintah Desa}

Penelitian ini bertujuan seberapa pengaruh Peran Perangkat Desa terhadap akuntabilitas Pemerintah Desa. Dari hasil pengujian hipotesis ditemukan bahwa tingkat signifikansi untuk variabel kompetensi adalah 0,009 lebih kecil dibandingkan dengan $\alpha$ sebesar 0,05 (5\%). Hal ini berarti, Peran Perangkat Desa memiliki pengaruh positif dan signifikan terhadap akuntabilitas Pemerintah Desa sekabupaten Solok. Hasil ini juga sejalan dengan penilitian yang dilakukan oleh Neny Tri Indrianasari (2016) yang menjelaskan bahwasanya perangkat desa cukup berperan dalam pengelolaan keuangan desa dan secara 
keseluruhan pelaksanaan pengelolaan keuangan desa sesuai dengan Permendagri No. 113 Tahun 2014.

Penelitian ini juga didukung oleh Widjaja (2018) bahwa perangkat desa telah berperan dalam pengelolaan dana desa. Ini dapat dilihat dari proses perencanaan penggunaan keuangan desa, perangkat desa memberikan masukan tentang rancangan APB Desa kepada Kepala Desa dan/atau BPD, perangkat desa terlibat dalam proses pelaksanaan penggunaan keuangan desa, perangkat desa bersama dengan Kasi, menyusun RAB, memfasilitasi proses pengadaan barang dan jasa, mengelola atau melaksanakan pekerjaan terkait kegiatan yang telah ditetapkan dalam Perdes tentang APB Desa, perangkat desa memberikan masukan terkait perubahan $\mathrm{APB}$, perangkat desa terlibat dalam proses penatausahaan penggunaan keuangan desa, perangkat desa meminta informasi, memberikan masukan, melakukan audit partisipatif.

Hasil penelitian ini menujukan pengaruh positif terhadap akuntabilitas pemerintah desa dalam mengelola alokasi dana desa, itu artinya responden setuju bahwa sistem peran perangkat desa sangat berpengaruh kepada akuntabilitas pemerintah desa dalam mengelola alokasi dana desa. Dari hasil pengujian tersebut, dapat disimpulkan bahwa semakin tinggi Peran Perangkat Desa maka akan meningkatkan akuntabilitas Pemerintah Desa tersebut.

\section{Pengaruh Kualitas Penyajian Laporan Keuangan Terhadap Akuntabilitas Pemerintah Desa}

Penelitian ini bertujuan seberapa pengaruh kualitas penyajian laporan keuangan terhadap akuntabilitas Pemerintah Desa. Dari hasil pengujian hipotesis ditemukan bahwa tingkat signifikansi untuk variabel kompetensi adalah 0,009 lebih kecil dibandingkan dengan $\alpha$ sebesar 0,05 (5\%). Hal ini berarti, kualitas penyajian laporan keuangan memiliki pengaruh positif dan signifikan terhadap akuntabilitas Pemerintah Desa dikabupaten Solok, yang artinya semakin baik kualitas penyajian laporan keuangan akan meningkatkan akuntabilitas pemerintah desa dalam pengalokasian dana desa. Penelitian ini juga sejalan yang dilakukan oleh Nordiawan (2018) yang menyatakan bahwasanya penyajian laporan keuangan yang baik adalah salah satu faktor untuk meningkatkan akuntabilitas pengelolaan keuangan daerah. Oleh sebab itu pemerintah daerah harus bisa menyusun laporan keuangan sesuai dengan standar akuntansi pemerintahan yang diterima umum.

Penelitian ini juga didukung oleh Arum Frida Aprilia (2019) laporan keuangan desa disajikan tepat waktu dan wajar serta kekeliruan dalam penggunaan dapat dicegah. Lebih lanjut, penyajian laporan keuangan desa menggunakan istilah yang dapat dipahami oleh pengguna. Dengan demikian, laporan keuangan terkait penggunaan ADD yang disajiakan dapat memenuhi harapan pengguna. Ketika kualitas laporan keuangan dana desa baik, maka segala kegiatan yang berkaitan dengan pengelolaan dana desa khususnya bidang administrasi keuangan dapat dipertanggungjawabkan. Bentuk pertanggungjawaban tersebut harus dapat diakses oleh semua pihak sehingga akuntabilitas pengelolaan Alokasi Dana Desa dapat meningkat

Hasil penelitian ini menujukan pengaruh positif terhadap akuntabilitas pemerintah desa dalam mengelola alokasi dana desa, itu artinya responden setuju bahwa sistem kualitas penyajian laporan keuangan sangat berpengaruh kepada akuntabilitas pemerintah desa dalam mengelola alokasi dana desa. Dari hasil pengujian tersebut, dapat disimpulkan bahwa semakin tinggi kualitas penyajian laporan keuangan yang dimiliki oleh aparatur desa maka akan meningkatkan akuntabilitas Pemerintah Desa tersebut. 


\section{KESIMPULAN, KETERBATASAN, DAN SARAN \\ Kesimpulan}

Berdasarkan hasil analisis data dan pembahasan, maka dapat ditarik kesimpulan sebagai berikut :

1. Kompetensi bepengaruh positif signifikan terhadap akuntabilitas pemerintah desa sekabupaten Solok.

2. Sistem Pengendalian Internal bepengaruh positif signifikan terhadap akuntabilitas pemerintah desa sekabupaten Solok.

3. Peran Perangkat Desa bepengaruh positif signifikan terhadap akuntabilitas pemerintah desa sekabupaten Solok.

4. Kualitas Penyajian Laporan Keuangan bepengaruh positif signifikan terhadap akuntabilitas pemerintah desa sekabupaten Solok.

\section{Keterbatasan}

Meskipun peneliti telah berusaha merancang dan mengembangkan penelitian sedemikian rupa, namun masih terdapat beberapa keterbatasan dalam penelitian ini yaitu :

1. Ruang lingkup penelitian ini hanya beberapa desa dikabupaten Solok ini dikarenakan akses berpergian terbatas karena efek pademi covid 19 yang sedang mengalami kenaikan dan beberapa desa juga melakukan sistem lockdown.

2. Walaupun dalam pengisian angket sudah diupayakan secara teliti dan hati- hati, tentunya hal tersebut juga tidak lepas dari kemungkinan adanya responden yang mengisi kuesioner dengan tidak serius dan asal-asalan.

\section{Saran}

Penelitian ini memiliki beberapa kelemahan, antara lain variabel yang diuji hanya 4 yakni kompetensi, sistem pengendalian internal, peran perangkat desa, dan kualitas penyajian laporan keuangan, sedangkan faktor - faktor yang dapat mempengaruhi akuntabilitas pemerintah desa sangat banyak. Saran dari peneliti sebagai berikut : bagi penelitian selanjutnya sebaiknya memperluas ruang lingkup penelitian dan perlu mempertimbangkan dan menambahkan variabel lain yang juga mempengaruhi akuntabilitas pemerintah desa.

\section{DAFTAR PUSTAKA}

Aikin, Stephen K. 2011. An Examination of Government Internal Audit's Role in Improving Financial Performance. Journal of Public Finance and Management, 11 (4): 306-337.

Ainswort, Murray., N. Smith., dan A. Millership. 2007. Managing Performance Managing People. Jakarta. PT. Bhuana Imu Populer.

Andriani, U., \& Zulaika, T. (2019). Peran Perangkat Desa Dalam Akuntabilitas Pengelolaan Dana Desa. Jurnal Akademi Akuntansi (JAA), 2(2), 119-144.

Arum Frida Aprilia (2019) Pengaruh Kompetensi, Sistem Pengendalian Internal, Dan Kualitas Penyajian Laporan Keuangan Terhadap Akuntabilitas Pemerintah Desa. Jurnal Analisis Bisnis Ekonomi, 17(1), 44-56.

Astuti, Wardana (2016) Pengaruh Kompetensi Pemerintah Desa, Sistem Pengendalian Internal, Dan Aksesibilitas Laporan Keuangan Terhadap Akuntabilitas Pengelolaan Dana Desa Media Riset Akuntansi, Auditing \& Informasi vol 20.

Cheng, R.H., H.E. John., C. Susan,. dan K. Fall. 2002. Educating government Financial Managers: University collaboration between business.

Dura, J. (2016). Pengaruh akuntabilitas pengelolaan keuangan alokasi dana desa, kebijakan desa, dan kelembagaan desa terhadap kesejahteraan masyarakat. Jurnal Ilmiah Bisnis dan Ekonomi Asia, 10(2), 26-32. 
Diarespati (2017) Pengaruh Kompetensi dan Sistem Pengendalian Internal Terhadap Akuntabilitas Pemerintah Desa dalam Mengelola Alokasi Dana Desa (ADD). Jurnal berkala Akuntansi Keuangan Indonesia vol 2 tahun 2017

Ghozali. (2011). Aplikasi Analisis Multivariante dengan program SPSS. Edisi V. Semarang: Badan penerbit UNDIP.

Halim dan Abdullah, S. 2008. Hubungan dan masalah keagenan di pemerintahaan daerah: sebuah peluang penelitian anggaran dan akuntansi. Jurnal Akuntansi pemerintahan.

Hehanussa, S. J. (2015, May). Pengaruh Penyajian Laporan Keuangan Daerah dan Aksesibilitas Laporan Keuangan Daerah Terhadap Transparansi dan Akuntabilitas Pengelolaan Keuangan Daerah Kota Ambon. In Conference In Business, Accounting, And Management (CBAM) (Vol. 2, No. 1, pp. 82-90).

Indrianasari, N. T. (2017). Peran Perangkat Desa Dalam Akuntabilitas Pengelolaan Keuangan Desa (Studi Pada Desa Karangsari Kecamatan Sukodono). Jurnal Ilmiah Ilmu Akuntansi, Keuangan Dan Pajak, 1(2).

Kalbers, L. P., dan T. J. Fogarty. 1995. Professionalis and Its Consequences: A Study of Internal Auditors. A Journal of Practice and Theory. Spring 14 (1): 64-85.

Kurtz, M. J., dan A. Schrank. 2007. Growth and Governance: Models, Measures, and Mechanisms, The Journal of Politics 69 (2), May 2007, pp. 538-554.

Mada, S., Kalangi, L., \& Gamaliel, H. (2017). Pengaruh kompetensi aparat pengelola dana desa, komitmen organisasi pemerintah desa, dan partisipasi masyarakat terhadap akuntabilitas pengelolaan dana desa di Kabupaten Gorontalo. JURNAL RISET AKUNTANSI DAN AUDITING" GOODWILL", 8(2).

Mardiasmo. 2002. Otonomi dan Manajemen Keuangan Daerah. Andi Offset: Yogyakarta

Matamande, Wilson, Nyikahadzoi loveness. Taderera Ever, Mandimika Elinah. 2012. The effectiveness of internal control in Revenue Management: A Case Study of Zimbabwe Revenue Authority (ZIMRA). 1- 2 Journal of Case Research in Business and Economics University of Zimbabwe.

Narsa, Niluh Putu Dian Rosalina Handayani, and Isnalita Isnalita. "SAK ETAP Sebagai Solusi Overload Standar Akuntansi Bagi UMKM." EKUITAS (Jurnal Ekonomi dan Keuangan) 1, no. 1 (2017): 44-65.

Neny Tri Indrianasari (2018) Peran Perangkat Desa Dalam Akuntanbilitas Pengelolaan Keuangan Desa (Studi Pada Desa Karangsari Kecamatan Sukodono). Jurnal akuntansi keuangan dan pajak.

Nordiawan (2010) Pengaruh Penyajian Laporan Keuangan Daerah Dan Aksesibilitas Laporan Keuangan Daerah Terhadap Transparansi Dan Akuntabilitas Pengelolaan Keuangan Daerah Kota Ambon. Unnisula Sultan Agung Islamic University

Nurlaili. 2016. Pengaruh Penyajian Laporan keuangan Dan Aksesibilitas Laporan Keuangan Terhadap Akuntabilitas Pengelolaan Keuangan Daerah (Studi Pada SKPD Kabupaten Bengkalis). JOM Fekon Vol.3 No.1 (Februari) 2016.

Peraturan Pemerintah No. 60 Tahun 2008 tentang Sistem Pengendalian Intern Pemerintah.

Rahardjo, 2010, Pengantar Sosiologi Pedesaandan Pertanian, Gadjah Mada University

Robbins, S. P. 2007. Perilaku Organisasi, Konsep Kontroversi, Aplikasi. Jakarta:PT. Indeks . Gramedia. Edisi Kesepuluh.

Rudana, N. 2005. Pengaruh Komptensi Aparatur PEMDA dan Komunikasi Interpersonal terhadap Kualitas Pelayanan Publik di Kantor Kabupaten Gianyar. Jurnal Ekonomi. Universitas Diponegoro.

Scott, J.K. 2006. "E" the people: Do US municipal government websites support public involvement? Public Administration Review 66 (3): 341-353.

Soekanto, Soerjono. 2006. Sosiologi Suatu Ilmu Pengantar, Jakarta: PT. Raja GrafindoPersada. 
Sugiyono. (2017). Statistika untuk penelitian. Bandung: Alfabeta.

Supriyono , Bambang 2009. Responsivitas dan Akuntabilitas Sektor Publik. Jakarta : Gramedia

Sweetenia, A. M., Caesari, E. P. A., Aprillia, A. F., \& Purwantini, A. H. (2019). Pengaruh Kompetensi, Sistem Pengendalian Internal, Dan Kualitas Penyajian Laporan Keuangan Terhadap Akuntabilitas Pemerintah Desa. Jurnal Analisis Bisnis Ekonomi, 17(1), 44-56.

Uddin, S., dan T. Hoper. 2001.A Bangladesh soap opera: Privatization, accounting and regimes of controlin a less developed country. Accounting Organizations and Society26: 643-672.

Wibowo. (2014) Manajemen Kinerja. Edisi ke-empat Jakrta : Rajawai Pers.

Wida, S. A., Supatmoko, D., \& Kurrohman, T. (2017). Akuntabilitas Pengelolaan Alokasi Dana Desa (ADD) di Desa-Desa Kecamatan Rogojampi Kabupaten Banyuwangi. EJournal Ekonomi Bisnis Dan Akuntansi, 4(2), 148-152.

Widjaja (2018) Peran Perangkat Desa Dalam Akuntanbilitas Pengelolaan Keuangan Desa (Studi Pada Desa Karangsari Kecamatan Sukodono). Jurnal akuntansi keuangan dan pajak.

Widyatama, A., Novita, L., \& Diarespati, D. (2017). Pengaruh Kompetensi dan Sistem Pengendalian Internal Terhadap Akuntabilitas Pemerintah Desa dalam Mengelola Alokasi Dana Desa (ADD). Berkala Akuntansi dan Keuangan Indonesia, 2(2).

Yesinia, N. I., Yuliarti, N. C., \& Puspitasari, D. (2018). Analisis Faktor Yang Mempengaruhi Akuntabilitas Pengelolaan Alokasi Dana Desa (Studi Kasus pada Kecamatan Yosowilangun Kabupaten Lumajang). Jurnal Aset (Akuntansi Riset), 10(1), 105-112.

Yudianto, I., \& Sugiarti, E. (2018). Pengaruh Penerapan Sistem Pengendalian Instansi Pemerintah (SPIP) Terhadap Akuntabilitas Pengelolaan Dana Desa (Survei Pada Desa-Desa di Wilayah Kecamatan Klari, Kecamatan Karawang Timur, Kecamatan Majalaya dan Kecamatan Rengasdengklok Kabupaten Karawang). Jurnal Akuntansi dan Keuangan, 17(1). 